\title{
An Analysis of Forest Management Non-Conformities to FSC Standards in Different European Countries
}

\section{Aureliu Florin HALALISAN ${ }^{1}$, Florin IORAS ${ }^{2}$, Henn KORJUS ${ }^{3}$, Mersudin AVDIBEGOVIC 4 , Bruno MARIC ${ }^{4}$, Spela PEZDEVSEK MALOVRH ${ }^{5}$, Ioan Vasile ABRUDAN ${ }^{1,6 *}$}

\author{
1 "Transilvania" University of Brasov, Faculty of Silviculture and Forest Engineering, 1 Sirul Beethoven, 500123-Brasov, \\ Romania; aureliu.halalisan@unitbv.ro \\ ${ }^{2}$ Buckinghamshire New University, Queen Alexandra Road, High Wycombe, Bucks HP 11 2JZ, England; florin.ioras@bucks.ac.uk \\ ${ }^{3}$ Estonian University of Life Sciences, Institute of Forestry and Rural Engineering, Tartu, Estonia; henn.korjus@emu.ee \\ ${ }^{4}$ Faculty of Forestry, University of Sarajevo, Zagrebacka 20, 71000-Sarajevo, \\ Bosnia and Herzegovina; mavdibegovic@gmail.com; bruno.m.maric@gmail.com \\ ${ }^{5}$ Department of Forestry and Renewable Forest Resources, Biotechnical Faculty, University of Ljubljana, Večna pot 83, 1000 Ljubljana, \\ Slovenia; spela.pezdevsek.malovrh@bf.uni-lj.si \\ ${ }^{6}$ Academy of Romanian Scientists, 54 Splaiul Independentei, Sector 5, 050094-Bucharest, \\ Romania; abrudan@unitbv.ro (*orresponding author)
}

\begin{abstract}
The purpose of this study was to assess the most frequent non-conformities identified in different European countries in the processes of forest management certification according to FSC standards. A total of 31 active certificates from five countries (Bosnia and Herzegovina, Estonia, Romania, Slovenia and the United Kingdom) were analysed, including all active certificates (as of $1^{\text {st }}$ of June 2014) from three countries along with a sample of 13 FSC certificates issued in the UK and one certificate covering 95\% of the certified forest area in Slovenia. 253 non-conformities in relation to FSC standard requirements were identified as formulated by the audit teams and the most frequently identified non-conformities in the certification process were those related to Principle 6 - Environmental impact (34\%), Principle 4 - Community relations and worker's rights (17\%) and Principle 8 - Monitoring and Assessment (13\%). A slight positive correlation was noticed between the FSC certified area and the total number of non-conformities, with a closer link in the case of Principle 9 - Maintenance of high conservation value forests, and Principle 4. The non-conformities related to Principles 4, 6 and 9 appeared to be significantly influenced in occurrence by country development; less often in the UK compared with the other four countries.
\end{abstract}

Keywords: forest certification, community relations, corrective actions, environmental values

\section{Introduction}

Forest certification is a voluntary, non-regulatory process allowing, due to its consultative and participatory nature for the implication of all stakeholders (Abrudan, 2001). Regarded as a market mechanism, one of the perspectives of certification is providing market incentives in view of ensuring competitive forest management (Cashore et al., 2004; Gullison, 2003; Karna et al., 2003; Zakreski et al., 2004). While frequently challenged because of its lacking certain benefits, forest certification has in many cases led to changes in administration, monitoring and planning (Bass et al., 2001; Rametsteiner, 1999; Thornber, 1999).

The certification process requires verification of the degree to which each condition (indicator) of the FSC standard is met
(Nussbaum et al., 2002). Evaluation by FSC standard requirements as part of the certification process is conducted by an independent (third) party, called certification body, thus ensuring the credibility of the certification scheme. The certification body has to be impartial; it is liable for its decisions of issuing, withdrawing or suspending a certificate, and needs to ensure that no activity affects confidentiality, objectivity and impartiality of the certification process (ISO 1996). An important role of the certification process is with the assessment team (auditors) who are in charge for collecting and processing information in view of establishing the degree to which the standard is met (Nussbaum and Simula 2005). A further necessary competence of the audit team is to identify non-conformities and differentiate their respective severity (Nussbaum et al., 2002). 
The assessment (audit) concludes with the official report of the audit team. The report presents details of the auditing process, its scope and identified non-conformities. The nonconformities identified by the audit team provide an image of how the forest management unit is managed. A number of corrective actions are set in order for management to improve and meet FSC standard requirements. The report can represent an important indicator for the impact of forest certification on the forest management unit (Meijaard et al., 2011). The non-conformities represent irregularities in relation to the requirements of FSC standards for forest management (10 principles and 56 criteria) and being described in the audit report are turned into "objectives" for change or adaptation in forest management (Meijaard et al., 2011).

Non-conformities can be minor (when not systematic, having a limited, punctual impact) or major, when systematic and compromising an FSC Principle or Criterion (FSC, 2009). In addition the audit team can provide recommendations (observations) to the forest management unit undergoing certification, so that further deviations from FSC standard requirements are avoided in future. In the main assessment report the audit team is required to mention all identified nonconformities and their severity (minor - major). The indication of non-conformities is accompanied by requests for corrective action aimed at solving such irregularities. Prior to the final decision, the official report devised by the audit team will be submitted for analysis to at least one experienced independent observer with the technical knowledge required for assessing the report (FSC, 2009). The decision of certification is not taken by the audit team, but by the certification body, taking into consideration the comments made by the independent observers. This requirement has been established in order to reduce the degree to that auditors influence the final decision.

It is the aim of this paper to describe the most frequent non-conformities identified in different European countries in the processes of forest management certification according to FSC standards.

\section{Materials and Methods}

The study sample consisted of five European countries (Bosnia and Herzegovina, Estonia, Romania, Slovenia and the United Kingdom). A total of 31 active certificates from the five countries were analysed. All active certificates (as of $1^{\text {st }}$ of June 2014) from Bosnia and Herzegovina, Estonia and Romania were studied, along with 13 FSC certificates issued in the UK and one certificate covering $95 \%$ of the certified forest area in Slovenia. 253 non-conformities in relation to FSC standard requirements were identified as formulated by the audit teams (Table 1).

The study included the analysis of the official audit reports available on www.info.fsc.org platform. These were issued by
SGS, Rainforest Alliance, Soil Association Woodmark, and Control Union Certifications certification bodies. Type and severity of forest management non-conformities matched against the FSC standard were recorded in a database developed in Microsoft Excel, and the distributions of the identified non-conformities were traced and quantified. The non-conformities identified by the audit team were quantified by FSC Principles and Criteria, country, certified area, certificate type, and management type and development level of the country. Statistical correlations and differences were calculated aided by STATISTICA 7.0 software. Spearman correlation was used to establish the link between the certified area and the number of non-conformities. The MannWhitney $U$ test was applied to reveal the differences between two groups, while the differences between several groups were tested using Kruskal-Wallis Analysis of Variance (ANOVA) method, with a transgression probability of $\mathrm{p}=5 \%$.

\section{Context: one standard, different countries}

Bosnia and Herzegovina $(\mathrm{BiH})$ is a European country, with more than $45 \%$ forested surface (2.18 million ha), in some regions (Herzegovina) even up to $90 \%$ (Ioraș et al., 2007). More than $60 \%$ of the forest is part of 5 national and nature parks (Ioraş et al., 2009). BiH holds 4 certificates accounting for over 1.52 million hectares: Šume Republike Srpske, UnskoSanske šume, Hercegbosanske šume and Šume Tuzlanskog Kantona (FSC, 2014).

Estonia has an FSC certified area of over 1.1 million ha, which represents $53 \%$ of its forests. Three FSC certificates have been issued to State Forest Management Centre, Lembit Laks and Stora Enso Eesti AS (private forest management). Since Estonia's independence in 1991, FSC certification has been one of the most successful non-regulatory measures in state forest management (Ahas et al., 2006). Still, forest certification has not solved the main problems of Estonian forestry sector, like excessive exploitation or illegal logging, more frequent in private forests than in state managed ones (Ahas et al., 2006).

The forestry sector holds a considerable role in Romania, representing an important income source particularly in some rural areas (Abrudan et al., 2009). Ten FSC certificates were issued in Romania, accounting for 2.44 million ha of forest ( $36 \%$ of a total of 6.73 million ha of forested area). Romania is a wood and wood product exporter (Abrudan, 2012), and forest management and chain of custody certification are important aspects of the forestry and biodiversity conservation strategies (Hălălișan et al., 2012, Hălălișan et al., 2013, Stăncioiu et al., 2010).

Slovenia is one of the most forested countries in Europe. 1.18 million ha of forests cover more than a half of its territory (58.5\%). Most Slovenian forests are located within the area of beech, fir-beech and beech-oak sites (70\%), which have a relatively high production capacity (MAFF, 2016). In Slovenia

Table 1. Number of certificates and studied non-conformities

\begin{tabular}{lcccc}
\hline & Bosnia and Herzegovina & Estonia & Romania & Slovenia \\
\hline Certified area (ha) & $1,519,235$ & $1,177,048$ & $2,440,400$ & 235,281 \\
Number of certificates & 4 & 3 & $107,124.81^{*}$ & 1 \\
Total number of studied non-conformities & 23 & 9 & 154 & 21 \\
Weighting of non-conformities (\%) & 9 & 3.5 & 60.8 & 18.1 \\
\hline
\end{tabular}

${ }^{*}$ The 13 studied certificates from the UK represent 107,124.81 ha from a total of 1,612,392 ha (45 FSC certificates). 
636

two FSC certificates (of which one group certificate) were issued, representing 0.25 million ha of certified forest (approximately $21 \%$ of the total forested area).

The United Kingdom (UK) is one of the least wooded areas of Europe, with 13\% woodland cover (Forestry Commission, 2011) compared to an average of $37 \%$ for European Union (EU) countries (Forestry Commission, 2010). The area of woodland in the UK at 31 March 2010 was estimated to be 3.08 million ha. The UK is an important market for certified products (Kraxner and Rametsteiner, 2004). In the UK, 45 FSC certificates are active, representing 1.59 million ha of certified forest ( $52 \%$ of the total forested area).

\section{Results and Discussion}

\section{FSC principles}

The analysis of all non-conformities corresponding to the 31 FSC certificates in the five considered countries reveals that the non-conformities most frequently identified in the certification process are those relating to Principle 6 Environmental impact (34\%). Also quite frequent are nonconformities that have reference to Principle 4 - Community relations and worker's rights (17\%) and Principle 8 Monitoring and Assessment (13\%). Therefore, the distribution of the non-conformities according to the 10 FSC Principles shows that almost two thirds of all analysed nonconformities refer to Principles 6, 4, and 8 (Figure 1).

In Romania $41.6 \%$ of the non-conformities refer to Principle 6, and in Estonia and Slovenia they account for 33\% (Table 2). In $\mathrm{BiH}$ and Estonia $34.8 \%$ and $33.3 \%$ of nonconformities, respectively, refer to Principle 4, whilst in Slovenia $19 \%$ of the non-conformities are related to Principle 9 - Maintenance of High Conservation Value Forests (Table 2).

In the case of Principle 6 (Environmental impact) most non-conformities ( $37 \%$ of the non-conformities relating to this principle) are associated to criterion 6.5 and concern the absence of documents that require written action for the erosion control, minimising destructive effects during harvesting and wildlife conservation (Figure 3). Further frequent non-conformities to Principle 6 were identified in relation to criterion $6.6(20 \%)$.

Non-conformities were identified also in relation to the absence of non-chemical pest management methods or the lack of adequate equipment for the administration of chemicals. Criterion 6.7 refers to the storage of chemicals, solid or liquid organic waste and certain irregularities have been noticed in dedicated sites. The audit teams have also identified nonconformities related to the implementation of protection measures for rare or endangered species.

In the case of Principle 4, most of the non-conformities (49\%) refer to workers' rights and to the code of practice on health and safety in forestry work (safety equipment) (criterion 4.2). In many cases it is at this point that accident risk evaluation and risk reduction measures are required. Nonconformities have been recorded also in relation to criterion 4.5, because of the absence of mechanisms for solving complaints or granting damages (Figure 2).

A frequently signalled non-conformity is the lack of conflict or complaint solving procedures. The management plans also came short to include the results of social impact assessment (criterion 4.4) in some cases and this has been highlighted by the audit teams, accounting for $23 \%$ of the non-conformities identified for Principle 4 in the five considered countries.

Principle 8 includes requirements concerning monitoring and assessment. Most non-conformities (35\%) related to Principle 8 identified by analysing the certificates issued in the five countries concern criterion 8.2 (devising of monitoring procedures of the effect of operations on flora and fauna or the areas managed primarily for conserving biodiversity). The nonconformities of criterion 8.5 refer to the absence of public information on High Conservation Value Forests (HCVF). $18 \%$ of the non-conformities to Principle 8 are related to this criterion (Figure 4). Further problems identified were related to the traceability of wood (criterion 8.3), to the separation of wood originating from certified forests from wood obtained from non-certified ones, or to the labelling of wood (23\%).

Most FSC non-conformities identified worldwide also refer to the environmental impact of forest management and to ecology and biodiversity conservation issues (Principle 6). A study conducted in Sweden on over 400 non-conformities identified between 1996 and 2001 revealed that the nonconformities concerning ecological aspects are the most frequent $(66 \%)$, while only $25 \%$ relate to social aspects and even fewer (2\%) represent economic problems (Dahl, 2001). Thornber (1999) confirms the same results showing that in 156 certified forest management units, $38 \%$ of the identified non-conformities represented ecosystem conservation problems, and $37 \%$ required corrective actions for management improvement in areas with rare and endangered species. The results obtained by Gullison (2003) upon analysing audit reports of forest management units (30 certificates were randomly selected) also support the above considerations.

\section{Severity of non-conformities}

The period allowed for solving non-conformities varies according to their severity. Thus, minor non-conformities have to be solved within a year, while major ones no later than three months (FSC, 2009). A special situation is that of preconditions: major non-conformities which need to be solved before the certificate is issued. If the identified irregularities are not solved in time, minor non-conformities become major (to be corrected within three months at the most), and if the existing non-conformities already were major, the certificate will be suspended (FSC, 2009). Minor nonconformities represented approximately $88 \%$, while $10 \%$ of non-conformities were major in the case of the analysed certificates (Figure 5). Only $2 \%$ of the studied nonconformities were preconditions.

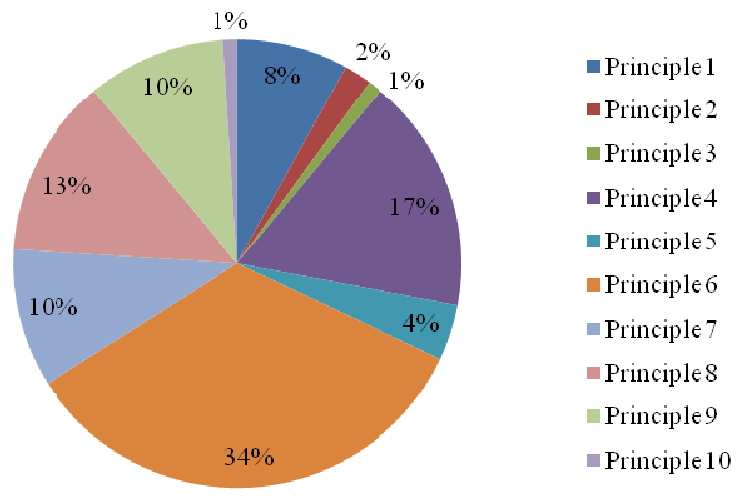

Fig. 1. Distribution of non-conformities by FSC Principles 
Table 2. Weighting of non-conformities by FSC Principle

\begin{tabular}{|c|c|c|c|c|c|}
\hline & Bosnia and Herzegovina (\%) & Estonia (\%) & Romania (\%) & Slovenia (\%) & UK (\%) \\
\hline Principle 1 & 8.7 & 11.1 & 5.8 & 9.5 & 10.9 \\
\hline Principle 2 & 0.0 & 0.0 & 1.3 & 4.8 & 6.5 \\
\hline Principle 3 & 0.0 & 0.0 & 0.0 & 0.0 & 4.3 \\
\hline Principle 4 & 34.8 & 33.3 & 14.9 & 4.8 & 17.4 \\
\hline Principle 5 & 0.0 & 11.1 & 4.5 & 4.8 & 4.3 \\
\hline Principle 6 & 13.0 & 33.3 & 41.6 & 33.3 & 19.6 \\
\hline Principle 7 & 8.7 & 0.0 & 11.0 & 4.8 & 13.0 \\
\hline Principle 8 & 13.0 & 0.0 & 12.3 & 19.0 & 17.4 \\
\hline Principle 9 & 21.7 & 11.1 & 8.4 & 19.0 & 2.2 \\
\hline Principle10 & 0.0 & 0.0 & 0.0 & 0.0 & 4.3 \\
\hline Total & 100.0 & 100.0 & 100.0 & 100.0 & 100.0 \\
\hline
\end{tabular}

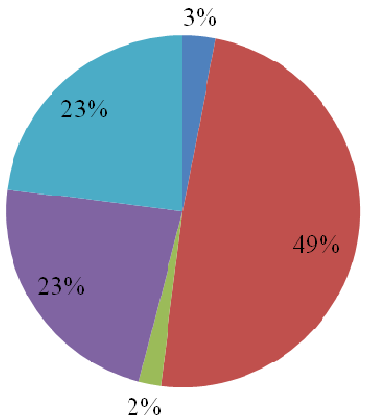

Fig. 2. Criteria related to Principle 4

\section{Correlations and differences between the non-conformities of FSC certificates}

\section{FSC Certified area and number of non-conformities}

The nature of the association described by the Spearman correlation is based on the analysis of two sets of ranks, determining the measure to that a monotonic relationship exists between two variables (Sheskin, 2004). A relationship between two variables is positive monotonic if the increase of one variable is associated with the increase of the other variable (Sheskin, 2004). Thus a significant positive correlation was identified between the certified surface and the number of nonconformities established for each certificate (Spearman $\mathrm{r}=0.583$ ). Normally the number of identified nonconformities should not be correlated with the certified area (Newsom et al., 2006). The total surface for which the certificate is issued influences the audit team only as to establishing the sample of the locations to be assessed. The audit team also needs to consider the provisions of FSC-STD01-001 standard (FSC, 2002): "The scale and intensity of forest management operations, the uniqueness of the affected resources, and the relative ecological fragility of the forest will be considered in all certification assessments". Still, in the case of certificates issued for large forest areas the probability of not meeting an FSC requirement is significantly greater. Upon comparing different types of certificates (single site, multiple site, small or low-intensity managed forest - SLIMF) and the number of non-conformities by means of the Kruskal-Wallis test, insignificant differences were noticed $(p=0.361)$. This was due to the fact that, for example, a single certificate can be issued for various forest surfaces, larger or smaller.

Upon analysing the relation between the certified surface and the number of non-conformities relating to each FSC Principle a slight positive correlation could be identified between the FSC certified area and the total number of non-

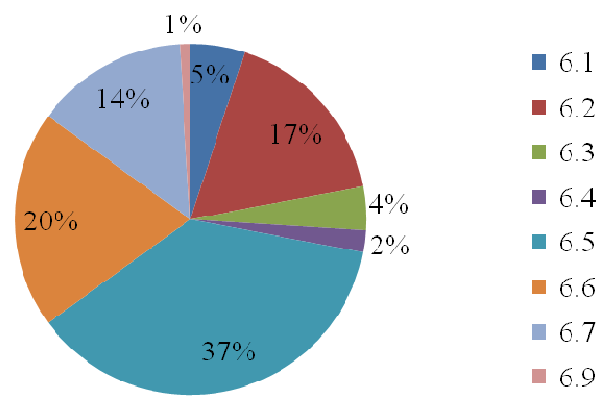

Fig. 3. Criteria related to Principle 6

conformities (Spearman $\mathrm{r}=0.583$ ). Also, it can be noticed that a closer link exists between Principle 9 (Spearman $r=0.602$ ), Principle 4 (Spearman $r=0.502$ ) and the certified area (Table 3). This can be explained by the fact that these principles depend more on the surface (for example the large HCVF areas, the complexity of large area management, more workers etc.).

\section{Number of non-conformities by country}

The Kruskal-Wallis One-Way Analysis of Variance by Ranks test was used to compare the 5 considered countries from the viewpoint of FSC non-conformities. Several independent groups were compared by using the number of non-conformities for each FSC Principle as dependent variables. The Kruskal-Wallis test is used to detect the differences between several independent groups. In the case of two independent groups the result will be equivalent to that of the Mann Whitney U test (Sheskin, 2004). If the result of the Kruskal-Wallis test is significant then differences exist between at least two medians of the set of independent groups (Sheskin, 2004).

Significant differences were recorded for Principles 4, 6, 7 and 9 (Table 4). Very significant differences were identified for the non-conformities of FSC Principle 6, revealing that this is interpreted differently by the audit team according to national specifics (this is mostly due the different situation in each country).

\section{Management type and number of non-conformities}

The non-parametric Mann-Whitney U test was used to detect the differences between private and state management from the viewpoint of FSC non-conformities. Thus two independent groups were compared (private and state forest management, respectively), by using the number of nonconformities for each FSC Principle as dependent variables. 
638

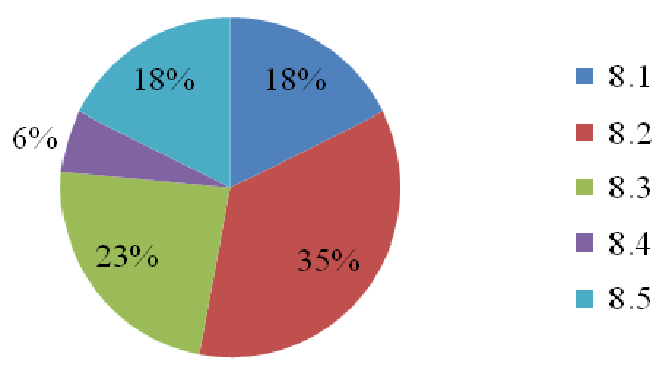

Fig. 4. Criteria related to Principle 8

Table 3. Spearman correlation between the certified area and the number of non-conformities related to each FSC Principle

\begin{tabular}{clc}
\hline Variable & \multicolumn{1}{c}{ Variable } & Spearman r \\
\hline \multirow{5}{*}{ FSC certified area } & Non-conformities Principle 1 & 0.375 \\
& Non-conformities Principle 2 & 0.240 \\
& Non-conformities Principle 3 & 0.000 \\
& Non-conformities Principle 4 & $\mathbf{0 . 5 0 2}$ \\
& Non-conformities Principle 5 & 0.334 \\
\cline { 2 - 3 } & Non-conformities Principle 6 & 0.319 \\
\cline { 2 - 2 } & Non-conformities Principle 7 & 0.266 \\
& Non-conformities Principle 8 & 0.323 \\
\cline { 2 - 2 } & Non-conformities Principle 9 & $\mathbf{0 . 6 0 2}$ \\
& Non-conformities Principle 10 & 0.285 \\
\hline
\end{tabular}

Table 5. Comparison of two groups (by forest management type: state and private) by means of the non-parametric Mann-Whitney $U$ test

\begin{tabular}{cll}
\hline $\begin{array}{c}\text { Independent } \\
\text { variable } \\
\text { (two groups) }\end{array}$ & \multicolumn{1}{c}{ Dependent variable } & $p$ value $^{*}$ \\
\hline & Non-conformities Principle 1 & $\mathbf{0 . 0 4 4}$ \\
& Non-conformities Principle 2 & 0,424 \\
& Non-conformities Principle 3 & 0.320 \\
& Non-conformities Principle 4 & $\mathbf{0 . 0 2 0}$ \\
& Non-conformities Principle 5 & 0.581 \\
Private - State & Non-conformities Principle 6 & 0.193 \\
forest management & Non-conformities Principle 7 & 0.145 \\
& Non-conformities Principle 8 & 0.050 \\
& Non-conformities Principle 9 & $\mathbf{0 . 0 0 4}$ \\
& Non-conformities Principle 10 & 0.490 \\
\hline${ }^{*}$ statistical significance at p $<0.05$ &
\end{tabular}

Upon testing these differences it can be noticed that there are no differences from the viewpoint of FSC nonconformities between the two types of management. In the case of Principle 1 - Compliance with laws and FSC Principles, Principle 4 -Community relations and worker's rights, and Principle 9 - Maintenance of high conservation value forests, the differences were significant (Table 5).

\section{Non-conformities in developed and less developed countries}

The statistical differences for non-conformities as a result of country economic development position according to the World Bank classification were also tested. The nonconformities related to Principle 4, Principle 6 and Principle 9 appear to be significantly influenced in occurrence by country development; less often in the United Kingdom compared with Bosnia and Herzegovina, Estonia, Romania and Slovenia (Table 6). One of the main benefits of forest certification is considered to be the periodical assessment and monitoring of forest management units (Rametsteiner and Simula, 2003).

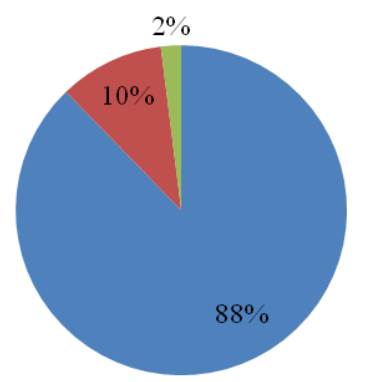

- Minor non-compliances

- Major non-compliances

Preconditions

Fig. 5. Severity of FSC non-conformities

Table 4. Comparison of several groups (countries) by means of the Kruskal-Wallis test

\begin{tabular}{clc}
\hline $\begin{array}{c}\text { Independent variables } \\
\text { (multiple groups) }\end{array}$ & \multicolumn{1}{c}{ Dependent variable } & ${ }^{*}$ p value \\
\hline & Non-conformities Principle 1 & 0.367 \\
& Non-conformities Principle 2 & 0.153 \\
& Non-conformities Principle 3 & 0.580 \\
& Non-conformities Principle 4 & $\mathbf{0 . 0 2 5}$ \\
& Non-conformities Principle 5 & 0.080 \\
Country & Non-conformities Principle 6 & $\mathbf{0 . 0 0 1}$ \\
& Non-conformities Principle 7 & $\mathbf{0 . 0 1 8}$ \\
& Non-conformities Principle 8 & 0.050 \\
& Non-conformities Principle 9 & $\mathbf{0 . 0 0 3}$ \\
& Non-conformities Principle 10 & 0.846 \\
\hline Statistical significance at $\mathrm{p}<0.05$ &
\end{tabular}

Table 6. Comparison of two groups (by more developed and less developed countries) using the non-parametric Mann-Whitney $U$ test

\begin{tabular}{clc}
\hline $\begin{array}{c}\text { Independent variable } \\
\text { (two groups) }\end{array}$ & \multicolumn{1}{c}{ Dependent variable } & $p$ value* \\
\hline \multirow{4}{*}{ More developed and less } & Non-conformities Principle 1 & 0,175 \\
& Non-conformities Principle 2 & 0,731 \\
& Non-conformities Principle 3 & 0,090 \\
& Non-conformities Principle 4 & $\mathbf{0 , 0 0 2}$ \\
& Non-conformities Principle 5 & 0,075 \\
& Non-conformities Principle 6 & $\mathbf{0 , 0 0 3}$ \\
& Non-conformities Principle 7 & 0,068 \\
& Non-conformities Principle 8 & 0,073 \\
& Non-conformities Principle 9 & $\mathbf{0 . 0 0 2}$ \\
\cline { 2 - 3 } & Non-conformities Principle 10 & 0,239 \\
\hline statistical significance at $\mathrm{p}<0.05$ &
\end{tabular}

Newsom and Hewitt (2005) show in a study conducted on a sample of 129 certificates issued by SmartWood certification body, stratified by country degree of development according to the World Bank, that in less developed countries there are statistically more chances for non-conformities in relation to workers' safety and training than in developed countries. Hain (2012) analysed the non-conformities occurrence rate using a stratified sample according to the location of certificate in either Eastern or Western Europe; the majority of nonconformities regarding endangered species, environmental impact assessment and harvesting impact were located in Eastern Europe. Also, health and safety aspects combined with stakeholders consultation appeared to be more often the case for non-conformities in Eastern Europe than it was in the western part of the continent (Hain, 2012). Therefore, the results of this study are in line with the previous research, clearly showing the importance of the development level in the forestry practice of each specific country. 


\section{References}

Abrudan IV (2001). Aspects regarding forest certification (in Romanian). Revista Pădurilor 2:41-44.

Abrudan IV, Marinescu V, Ionescu O, Ioras F, Horodnic SA, Sestras R (2009). Developments in the Romanian forestry and its linkages with other sectors. Notulae Botanicae Horti Agrobotanici Cluj-Napoca 37(2):14-21.

Abrudan IV (2012). A decade of non-state administration of forests in Romania: achievements and challenges. International Forestry Review 14(3):275-284.

Ahas R, Hain H, Mardiste P (2006). Forest Certification in Estonia. In: Cashore B, Gale F, Meidinger E, Newsom D (Eds). Confronting Sustainability: Forest Certification in Developing and Transitioning Countries, Yale School of Forestry and Environmental Studies Press pp 171-202.

Bass S, Thornber K, Markoupolus M, Roberts S, Grieg-Gran M (2001). Certification's impacts on forests, stakeholders and supply chains. Instruments for sustainable private sector forestry series. International Institute for Environment and Development, London.

Cashore B, Auld G, Newsom D (2004). Governing through markets: Forest Certification and the emergence of non-state authority. Yale University Press, New Haven,

Dahl L (2001). FSC I praktiken, [FSC in practice]. Swedish Society for Nature Conservation and WWF, Stockholm.

Forestry Commission (2010). Retrieved 2011 Sept 15 from http://www.forestry.gov.uk/inventory.

Forestry Commission (2011). Retrieved 2012 Sept 15 from http://www.forestry.gov.uk/inventory.

FSC (2002). FSC-STD-01-001 Standard: FSC Principles and Criteria for Forest Stewardship. Retrieved 2016 June 15 from https://ca.fsc.org/preview.fsc-std-01-001-v4-0-fsc-principlesand-criteria-for-forest-stewardship.a-832.pdf.

FSC (2009). FSC-STD-20-007 Standard: Forest management evaluations. Retrieved 2016 June 15 from https://ic.fsc.org/preview.fsc-std-20-007-v3-0-en-forestmanagement-evaluations.a-524.pdf.

FSC (2014). Retrieved 2015 Jan 15 from http://www.info.fsc.org.

Gullison RE (2003). Does certification conserve biodiversity? Oryx 37 (2):153-165.

Hain $H$ (2012). The role of voluntary certification in promoting sustainable natural resource use in transitional economies. PhD Thesis, University of Tartu, Estonia.

Hălălișan AF, Marinchescu M, Abrudan IV (2012). The evolution of forest certification: A short review. Bulletin of the Transilvania University of Brasov, Series II 5(54):35-42.

Hălălișan AF, Marinchescu M, Popa B, Abrudan IV (2013). Chain of custody certification in Romania: profile and perceptions of FSC certified companies. International Forestry Review 15(3):305-314.

Ioraș F, Abrudan IV, Dautbasic M, Avdibegovic M, Gurean D, Ratnasingam J (2009). Conservation gains through HCVF assessments in Bosnia-Herzegovina and Romania. Biodiversity and conservation 18(13):3395-3406.

Ioraș F, Dautbasic M, Maunaga R, Suess W (2007). The identification of High Conservation Value Forests (HCVF) to support the certification of sustainable forest management in Bosnia and Herzegovina. In: Abrudan IV, Spârchez G, Oprea I, Simon D, Ignea G, Chitea G (Eds). Proceedings of "International Symposium Forest and Sustainable Development” Braş, Rovania, pp 219-226.

ISO (1996). ISO/IEC 65 Guide: General requirements for certification bodies. Retrieved 2016 Jan 15 from http://www.iso.org/iso/catalogue_detail.htm?csnumber=267 96.

Karna J, Hansen E, Juslin H (2003). Environmental activity and forest certification in marketing of forest products: A case study in Europe. Silva Fennica 37(2):253-267.

Kraxner F, Rametsteiner E (2004). Public procurement policies boost demand: certified forest products markets 2003-2004. In: Forest Products Annual Market Review 2003-2004, Timber Bulletin 57(3). United Nations, Geneva pp 61-66.

MAFF (2016). Summary of the Report on Slovenian Forests and Forestry 2007-2014. Birografika BORI d.o.o., Ljubljana.

Meijaard E, Sheil D, Guariguata MR, Nasi R, Sunderland T, Putzel L (2011). Ecosystem services certification. Opportunities and constraints. Occasional Paper 66. CIFOR, Bogor.

Newsom D, Bahn V, Cashore B (2006). Does forest certification matter? An analysis of operation-level changes required during the SmartWood certification process in the United States. Forest Policy and Economics 9(3):197-208.

Newsom D, Hewitt D (2005). The global impacts of SmartWood certification. Final Report, Trees Program, Rainforest Alliance.

Nussbaum R, Jennings S, Garforth M (2002). Assessing forest certification schemes: a practical guide. Proforest, UK.

Nussbaum R, Simula M (2005). The forest certification handbook. 2nd Edition. London, Earthscan.

Rametsteiner E (1999). Sustainable Forest Management Certification - Framework Conditions, Systems Design and Impact Assessment. MCPFE Liaison Unit, Vienna.

Rametsteiner E, Simula M (2003). Forest certification-an instrument to promote sustainable forest management? Journal of Environmental Management 67(1):87-98.

Sheskin JD (2004). Handbook of parametric and nonparametric statistical procedures. Third edition. Florida, CRC Press.

Stancioiu PT, Abrudan IV, Dutca I (2010). The Natura 2000 ecological network and forests in Romania - some implications on management and administration. International Forestry Review 12:106-113.

Thornber K (1999). Overview of global trends in FSC certificates. Instruments for Sustainable Private Sector Forestry Series. International Institute of Environment and Development, London.

Zakreski S, Doak S, Evertz M (2004). Matching business values with forest certification systems. Metafore Report, Portland. 